13 Research Journal of Accounting and Business Management (RJABM); P-ISSN: 2580-3115; E-ISSN: 2580-3131

\title{
ANALISIS PERHITUNGAN PAJAK PENGHASILAN KARYAWAN PADA PT.KDC SAMARINDA
}

\author{
Mardiana, S.E., M.M \\ Fibby Rismawati
}

\author{
Universitas 17 Agustus 1945 Samarinda \\ J1. Ir. H. Juanda No. 80, 75124, Indonesia \\ mardiana@untag-smd.ac.id
}

The purpose of this study is to determine the calculation of income tax (PPh) Article 21 for employees of PT.KDC Samarinda is in accordance with Law Number 36 of 2008 and Minister of Finance Regulation Number 101 / PMK.010 / 2016. Tax is a compulsory contribution to the State owed by an individual or entity that is a force based on the Law, by not getting compensation directly and used for the State's needs for the greatest prosperity of the people. Income is any additional economic capability that is received or obtained by taxpayers, both from Indonesia and from outside Indonesia, which can be used for consumption or to increase the wealth of the taxpayer concerned, by name and in any form.Article 21 Income Tax is a tax on income in the form of salary, wages, honorarium, allowances, and other payments in whatever name and form in connection with employment or position, services, and activities carried out by individuals of domestic tax subjects, as referred to in Article 21 Income Tax Law.The analytical tool used in this study is the amount of individual taxpayer tariffs Article 17 of Law Number 36 of 2008. Changes in the amount of Non-Taxable Income (PTKP) according to Minister of Finance Regulation 101 / PMK.010 / 2016 and office fees according to UU-Law Number 36 of 2008 article 21 paragraph 3The results of this study of Income Tax Calculation (PPh) of employees with permanent employee status at PT. KDC Samarinda are in accordance with Law Number 36 of 2008 and Regulation of the Minister of Finance Number 101 / PMK.010 / 2016

Keywords: PPh 21, Permenkeu No 101/PMK.010/2016, UUD No 36 of 2008

\section{PENDAHULUAN Latar Belakang}

Pajak merupakan salah satu sumber penerimaan Negara yang diharapkan dapat mengurangin ketergantungan Negara kita terhadap hutang luar negeri. Sektor pajak dianggap pilihan yang tepat karena jumlahnya relatif stabil. Pembayaran pajak merupakan perwujudan dari kewajiban pengabdian dan peran serta wajib pajak untuk secara langsung dan bersama-sama melaksanakan pembiayaan negara dan pembangunan nasional. Sesuai falsafah undang-undang perpajakan, membayar pajak bukan hanya merupakan kewajiban, tetapi merupakan hak dari setiap warga negara untuk ikut berpartisipasi dalam bentuk peran serta terhadap pembiayaan negara dan pembangunan nasional. 
Pajak dilihat dari sektor ekonomis merupakan pemindahan sumber daya sektor privat menjadi sektor publik. Pemindahan tersebut akan mempengaruhi daya beli atau kemampuan belanja sektor privat. Agar tidak terjadi gangguan yang serius terhadap jalannya perusahaan maka pemenuhan kewajiban perpajakan harus di kelolah dengan baik.(Vinry Y Pangandaheng, Inggriani Elim, Heince R.N Wokas 2017).

Sistem yang diterapkan pemerintah Indonesia khususnya pajak penghasilan adalah self assessment system yaitu perpajakan yang memberikan kepercayaan dan bertanggung jawab kepada masyarakat wajib pajak atau penerimaan penghasilan untuk menghitung ,membayar dan melaporkan sendiri jumlah pajak yang harus di bayar, termasuk dalam pengertian adalah memberi wewenang kepercayaan dan tanggung jawab kepada wajib pajak untuk menghitung, memotong, menyetor dan melaporkan besarnya pajak yang harus dipotong dan disetor atas penghasilan orang pribadi sehubungan dengan pekerjaan, jasa dan kegiatan.

Pemotongan pajak penghasilan karyawan dikatakan sesuai apabila perhitungan sudah sesuai dengan ketentuan Undang-Undang Nomor 36 Tahun 2008 tentang Pajak Penghasilan. Untuk pemotongan Pajak
Penghasilan dengan status pegawai tetap harus sesuai dengan pasal 21 Ayat (3) yaitu penghasilan pegawai tetap atau pensiunan yang dipotong pajak setiap bulan adalah jumlah penghasilan bruto setelah dikurangi dengan biaya jabatan atau biaya pensiun yang besarnya ditetapkan dengan Peraturan Menteri Keuangan, iuran pensiun, dan Penghasilan Tidak Kena Pajak dan Peraturan Menteri Keuangan tentang penyesuaian besarnya penghasilan tidak kena pajak.

Perhitungan pajak penghasilan karyawan dengan status pegawai tetap yang tidak memiliki Nomor Pokok Wajib Pajak ( NPWP ) harus sesuai dengan ketentun $\mathrm{PPh}$ pasal 21 ayat (5a) Undang - Undang Nomor 36 Tahun 2008 yaitu besarnya tarif sebagaimana dimaksud pada ayat (5) yang diterapkan terhadap wajib pajak yang tidak memilik NPWP lebih tinggi 20\% ( dua puluh persen ) dari tarif yang diterapkan terhadap Wajib Pajak yang memiliki Nomor Pokok Wajib Pajak (NPWP).

Perhitungan pajak penghasilan dapat dikatakan belum sesuai apabila perhitungan tersebut belum sesuai dengan UndangUndang Nomor 36 Tahun 2008 tentang Pajak Penghasilan dan Perusahaan tidak akan memotong pajak penghasilan karyawan dengan status penghasilan pegawai tetap 
15 Research Journal of Accounting and Business Management (RJABM); P-ISSN: 2580-3115; E-ISSN: 2580-3131

yang penghasilannya sudah melebihi ketentuan penghasilan tidak kena pajak yang ditetapkan oleh Peraturan Menteri Keuangan Nomor 101/PMK.010/2016. Dengan dasar tersebut diatas dan untuk kepentingan penelitian ini, penulis memilih PT.KDC Samarinda sebagai objek penelitian. Agar penulis dapat melihat jelas bagaimana perhitungan $\mathrm{PPh}$ Pasal 21 terhadap gaji karyawan yang di potong oleh PT. KDC Samarinda berdasarkan Undang-Undang Nomor 36 Tahun 2008. PT. KDC beralamat di Jalan Jakarta II Perum Samalou Residence Blok AB/7 Rt.081 Samarinda. Perusahaan ini bergerak di bidang jasa kontraktor pertambangan batu bara.

Penelitian ini difokuskan pada perhitungan PPh Pasal 21 PT. KDC di Samarinda yang dipotong setiap bulan terhadap gaji karyawan status pegawai tetap dengan Undang-Undang No 36 Tahun 2008 dan Peraturan Menteri Keuangan Nomor 101/PMK.010/2016. Pemotongan PPh Pasal 21 yang dilakukan oleh pihak Finance dan Tax. Penghasilan bruto yang diterima karyawan PT. KDC Samarinda berkisar Rp.2.500.000 sampai dengan Rp.12.000.000 setiap bulannya.

\section{Rumusan Masalah}

Berdasarkan uraian pada latar belakang, maka dapat dirumuskan masalah peneliti sebagai berikut :

“Apakah Perhitungan Pajak Penghasilan $(\mathrm{PPh})$ karyawan dengan status pegawai tetap pada PT KDC sudah sesuai dengan UndangUndang Nomor 36 Tahun 2008 dan Peraturan Menteri Keuangan Nomor 101/PMK.010/2016?

\section{DASAR TEORI \\ Akuntansi Perpajakan Pengertian Akuntansi Perpajakan}

Akuntansi Pajak adalah suatu seni dalam mencatat, menggolongkan, mengihtisarkan serta menafsirkan transaksi-transaksi finansial yang dilakukan oleh perusahaan dan bertujuan menetukan jumlah penghasilan kena pajak (penghasilan yang digunakan sebagai dasar penetapan beban dan pajak penghasilan yang terutang) yang diperoleh atau diterima dalam satu tahun pajak yang dipakai sebagai dasar penetapan beban atau pajak penghasilan yang terutang oleh perusahaan sebagai wajib pajak, maka fungsi Akuntansi Pajak merupakan sebagai mengelola data kuantitatif yang akan digunakan untuk menyajikan laporan keuangan yang memuat perhitungan pajak.

Penulis mencoba menjelaskan pengertian akuntansi pajak dari beberapa sudut pandang yang berbeda. 
Akuntansi Pajak adalah akuntansi yang berkaitan dengan perhitungan perpajakan dan mengacu pada peraturan dan perundangundanan perpajakan beserta aturan pelaksanaannya (Muljono, 2009:1). Akuntansi Pajak merupakan bagian dari akuntansi komersil. Akuntansi pajak tidak memiliki standar seperti akuntansi komersil yang diatur dalam Standar Akuntansi Standar (SAK). Akuntansi pajak hanya digunakan untuk mencatat transaksi yang berhubungan dengan perpajakan (Agoes, 2009:7). Dengan adanya akuntansi pajak lebih mudah menyusun SPT.

Berdasarkan uraian diatas, akuntansi pajak dapat didifinisakan sebagai sistem akuntansi yang mengkalkulasi, menangani, mencatat,bahkan menganalisa dan membuat strategi perpajakan sehubungan dengan kejadian-kejadian ekonomi atau transaksi perusahaan. Akuntansi pajak yang berkaitan dengan perhitungan perpajakan dan mengacu pada peraturan dan perundangundangan perpajakaan beserta aturan pelaksanaannya. Akuntansi pajak berfungsi mengolah data kuantitatif yang akan digunakan untuk menyajikan laporan keuangan yang memuat perhitungan perpajakan.

\section{Pajak}

\section{Pengertian Pajak}

Pajak adalah iuran dari rakyat kepada pemerintah berdasarkan undang-undang yang berlaku atau juga biasa didefinisikan bahwa pajak adalah pengalihan kekayaan dari sektor swasta ke sektor publik yang dapat dipaksakan, dana yang terkumpul dari pajak digunakan baik langsung ataupun tidak langsung untuk membiayai kebutuhan pemerintah suatu negara dengan penjelasan sebagai berikut "iuran dari rakyat kepada negara" artinya yang berhak memungut pajak hanyalah Negara.iuran tersebut berupa uang ( bukan barang). "dapat dipaksakan" artinya bila utang pajak tidak dibayar, utang itu dapat ditagih dengan menggunakan kekerasan, seperti surat paksa dan sita.

Pajak adalah kontribusi wajib kepada Negara yang terutang oleh orang pribadi atau badan yang bersifat memaksa berdasarkan Undang-Undang, dengan tidak mendapatkan imbalan secara langsung dan digunakan untuk keperluan Negara bagi sebesar-besarnya kemakmuran rakyat (Diana, 2009:1).

Pajak adalah iuran wajib berupa uang atau barang yang dipungut oleh pengusaha berdasarkan norma-norma hukum, guna menutup biaya produksi barang-barang dan jasa kolektif dalam mencapai kesejaahteraan umum (Muljono, 2010:1). 
Berdasarkan uraian di atas, maka dapat disimpulkan bahwa unsur yang melekat pada pengertian pajak yaitu: Pajak dipungut berdasarkan Undang-Undang serta aturan pelaksanaannya. Pajak sifatnya dapat dipaksakan, hal ini berarti pelanggaran atas aturan perpajakan akan berakibat adanya sanksi. Dalam pembanyaran pajak tidak dapat adanya kontraprestasi langsung oleh pemerintah. Pajak dipungut untuk membiayai pengeluaran rutin dan sumber utama untuk membiayai public investment. Pajak dipungut oleh Negara baik pusat maupun pemerintah daerah.

\section{Fungsi Pajak}

Definisi pajak yang diberikan para ahli pajak dapat disimpulkan ada 2 (dua) fungsi pajak sebagaimana yang telah disebutkan oleh Mardiasmo (2016:4)

a. Fungsi anggaran (Budgetair)

Pajak yang berfungsi sebagai salah satu sumber dana bagi pemerintah untuk membiayai pengeluaran-pengeluarnnya.

b. Fungsi mengatur (cregulerend)

Pajak berfungsi sebagai alat untuk mengatur atau melaksanakan kebijaksanaan pemerintah dalam bidang sosial dan ekonomi.
Contoh :

1) Pajak yang tinggi dikenakan terhadap minuman keras untuk mengurangi konsumsi minuman keras

2) Pajak yang tinggi dikenakan terhadap barang-barang mewah untuk mengurangi gaya hidup konsumtif

Fungsi budgetair adalah fungsi yang letaknya pada sektor publik, dimana pajak merupakan suatu sumber pemasukan uang sebanyak-banyaknya ke kas Negara, yang dapat digunakan untuk membiayai pengeluaran-pengeluaran Negara.

Fungsi Regulerend digunakan sebagai alat untuk mencapai tujuan-tujuan tertentu yang letaknya diluar sektor keuangan dan fungsi mengatur itu ditujukan kepada sektor swasta.

\section{Pajak Penghasilan (PPh) Pasal 21}

\section{Pengertian Pajak Penghasilan Pasal 21}

Berdasarkan pernyataan Standar Akuntansi Keuangan No 46 memberikan definisi mengenai pajak penghasilan adalah "pajak yang dihitung berdasarkan peraturan perpajakan dan pajak ini dikenakan atas penghasilan kena pajak perusahaan.”

Menurut Mardiasmo (2016: 197), Pajak Penghasilan Pasal 21 adalah pajak atas 
penghasilan

berupa

gaji,upah,honorarium,tunjangan,dan

pembayaran lain dengan nama dan dalam bentuk apa pun sehubungan dengan pekerjaan atau jabatan, jasa, dan kegiatan yang dilakukan oleh orang pribadi Subjek pajak dalam negeri, sebagaimana dimaksud dalam Pasal 21 Undang-Undang Pajak Penghasilan.

\section{Pajak Penghasilan adalah} "Suatu pungutan resmi yang ditujukan kepada masyarakat yang berpenghasilan atau atas penghasilan yang diterima atau diperoleh dalam tahun pajak untuk membiayai pengeluaran-pengeluaran Negara" (Supramono \& Theresia Woro Damayanti, 2010:37

Jadi, dari beberapa pengertian di atas maka penulis dapat menyimpulkan bahwa pajak penghasilan adalah pungutan resmi yang ditujukan kepada masyarakat atas penghasilan berupa gaji, upah, honorarium, tunjangan dan pembayaran lain dengan nama dan dalam bentuk apa pun sehubungan dengan pekerjaan atau jabatan, jasa, dan kegiatan yang lainnya dalam tahun pajak untuk membiayai pengeluaran-pengeluaran Negara.

\section{Nomor Pokok Wajib Pajak (NPWP)} Menurut Muljono (2008:1), Nomor Pokok Wajib Pajak adalah Nomor yang diberikan kepada Wajib Pajak sebagai sarana dalam administrasi perpajakan yang dipergunakan sebagai tanda pengenal diri atau identitas wajib pajak dalam melaksanakan hak dan kewajiban perpajakannya.

Wajib Pajak mendaftarkan diri untuk memperoleh NPWP ke kantor pelayanan pajak yang wilayah kerjanya meliputi tempat tinggal atau tempat kedudukan wajib pajak.

Wajib Pajak yang telah terdaftar akan memperoleh Nomor Pokok Wajib Pajak (NPWP). NPWP terdiri dari 15 digit, yaitu 9 (sembilan) digit pertama merupakan Kode Wajib Pajak dan 6 (enam) digit berikutnya merupakan Kode administrasi atau kode wilayah Perpajakan.

Contoh: 81.602.122.4-722.000 kode tersebut menjelaskan Wajib Pajak di KPP Pratama Samarinda.

\section{Alat Analisis \\ Penentuan alat analisis harus dilakukan dengan tepat agar permasalahan yang dihadapi dapat diukur dan dipecahkan. Alat analisis yang digunakan sebagai berikut :}


19 Research Journal of Accounting and Business Management (RJABM); P-ISSN: 2580-3115; E-ISSN: 2580-3131

a. Tentang Perubahan Besarnya Tarif Bagi Wajib Pajak Pasal 17, UU PPh 21 No. 36 tahun 2008.

Gambar 3.1: Batas tarif bagi Wajib Pajak menurut UU PPh 21 Nomor 36 Tahun 2008 No Lapisan Penghasilan Kena Pajak Tarif pajak

1 Sampai dengan Rp 50.000.000 5\%

2 Di atas Rp. 50.000.000 s.d Rp. 250.000.000 15\%

3 Di atas Rp 250.000.000 s.d Rp. 500.000.000 25\%

4 Di atas Rp. 500.000.000 30\%

Sumber Data: Mardiasmo (2016: 178)

b. Tentang Perubahan Besarnya Penghasilan Tidak Kena Pajak (PTKP) Pasal 17

Gambar 3.2 : Batas tarif PTKP menurut UU PPh Nomor 36 Tahun 2008

\begin{tabular}{clc} 
No & \multicolumn{1}{c}{ Keterangan } & Besar PTKP \\
\hline \multirow{2}{*}{1} & Untuk Wajib Pajak & Rp. 54.000.0OO \\
\cline { 2 - 3 } 2 & Tambahan WP yang kawin & Rp. 4.500.00O \\
\cline { 2 - 3 } 3 & Tambahan Isteri yang bekerja & Rp. 54.000.00O \\
\cline { 2 - 3 } 4 & Tambahan Tanggungan & Rp. 4.500.00O \\
& paling banyak 3 ( tiga) orang & \\
\cline { 2 - 3 }
\end{tabular}

(Sumber : Peraturan Menteri Keuangan Nomor 101/PMK.010/2016)

c. Biaya Jabatan

Besarnya biaya jabatan yang di dapat di kurangkan dari penghasilan bruto untuk Perhitungan pemotongan Pajak Penghasilan bagi karyawan tetap sebagaimana di maksud dalam Pasal 21 ayat 3 Undang-Undang Nomor 7 Tahun 1983 tentang Pajak Penghasilan

d. Perhitungan dan Pemotongan PPh Pasal 21 sebagaimana telah beberapa kali diubah terakhir dengan Undang-Undang

Nomor 36 Tahun 2008 ditetapkan sebesar 5 $\%$ ( lima persen ) dari penghasilan bruto, setingi - tingginya Rp.6.000.000., setahun atau Rp.500.000., sebulan. 


\section{Gambar 3.3 : Perhitungan dan Pemotongan Pajak Penghasilan Pasal 21}

\begin{tabular}{|c|c|c|}
\hline a. Penghasilan Bruto Sebulan & & \\
\hline Gaji & Rp. $\mathbf{x x x}$ & \\
\hline Jumlah Jam Lembur dalam 1 bulan & Rp. $\mathbf{x} \times \mathbf{x}$ & \\
\hline Tunjangan Fungsional & Rp. $\mathbf{x x x}$ & \\
\hline Tunjangan Struktual & Rp. $\mathbf{x x x}$ & \\
\hline Jumlah Penghasilan Bruto Sebulan & & Rp. $\mathbf{x x x}$ \\
\hline b. Potongan Sebulan & & \\
\hline Biaya Jabatan & Rp. $\mathbf{x x x}$ & \\
\hline ( $5 \% \times$ Penghasilan bruto sebulan) & & \\
\hline Maksimal Rp.500.000 sebulan & & \\
\hline Maksimal Rp. 6.0OO.OOO setahum & & \\
\hline Iuran BPJS & Rp. $\mathbf{x x x}$ & \\
\hline Jumlah Potongan Sebulan & & Rp. $\mathbf{x x x}-$ \\
\hline c. Penghasilan Netto sebulan & & \\
\hline d. Penghasilan Netto setahun $(x 12)$ & & Rp. $\mathbf{x x x}$ \\
\hline e. pajak Penghasilan Pasal 21 Terutang setahun & & Rp. $\mathbf{x x x}$ \\
\hline f. Pajak Penghasilan Pasal 21 setahun & & Rp. $\mathbf{x x x}$ \\
\hline
\end{tabular}

(Sumber : Peraturan Direktur Jendral Pajak Nomor : PER-16/PJ/2016)

\section{ANALISIS}

Berdasarkan data yang diperoleh dari hasil penelitian pada PT. KDC mengenai perhitungan pajak penghasilan ( $\mathrm{PPh}$ ) pasal 21 yang telah diterapkan oleh PT. KDC, maka dalam bab ini peneliti akan menganalisis tentang perhitungan pajak penghasilan ( $\mathrm{PPh}$ ) pasal $21 \mathrm{PT}$. KDC dengan menyesuaikan dengan UndangUndang Nomor 36 Tahun 2008 tentang pajak penghasilan dan pelaporan Pajak Penghasilan dalam SPT tahunan $\mathrm{PPh}$ Orang Pribadi Tahun 2018 sebagaimana ditetapkan dalam Peraturan Menteri Keuangan Nomor 101/PMK.010/2016 terhadap gaji karyawan tetap. PT.KDC Memiliki \pm 1.300 karyawan di lokasi tambang dan 32 karyawan di Head Office, karena keterbatasan waktu maka penulis hanya mengambil sampel 32 karyawan tetap yang ada di Head Office.

Pada tabel yang telah dipaparkan terlihat bahwa penghasilan sebulan dan jumlah pajak penghasilan ( $\mathrm{PPh}$ ) Pasal 21 dalam setiap bidang pekerjaan berbeda-beda. Hal ini disebabkan karena penghasilan sebulan yang didapat dari kegiatan overtime, tunjangan tetap dan tunjangan tidak tetap yang di dapat oleh setiap karyawan tidak 
21 Research Journal of Accounting and Business Management (RJABM); P-ISSN: 2580-3115; E-ISSN: 2580-3131

sama dan status karyawan tetap tersebut yaitu, TK (Tidak Kawin, K/0, K/1, K/2,
$\mathrm{K} / 3$, (Kawin mempunyai anak 1 sampai 2 orang ).

\begin{tabular}{|c|c|c|c|c|c|c|c|c|c|c|c|c|c|}
\hline No & NPWP & Nama & Jabatan & Status & $\begin{array}{l}\text { Penghasilan } \\
\text { bruto sebulan ( } \\
\text { Rp) }\end{array}$ & $\begin{array}{l}\text { penghasilan } \\
\text { netto sebulan } \\
\text { (Rp) }\end{array}$ & $\begin{array}{l}\text { penghasilan netto } \\
\text { setahun ( Rp) }\end{array}$ & PTKP Setahun & PKP setahun & $\begin{array}{c}\text { pph pasal } 21 \\
\text { setahun KDC } \\
\text { ( Rp) }\end{array}$ & $\begin{array}{c}\text { pph pasal } \\
21 \text { sebulan } \\
\text { KDC ( Rp) }\end{array}$ & $\begin{array}{l}\text { pph pasal } 21 \\
\text { setahun } \\
\text { nomor } 36 \\
\text { tahun } 2008 \text { ( } \\
\text { Rp) }\end{array}$ & $\begin{array}{c}\text { pph pasal } \\
21 \text { sebulan } \\
\text { nomor } 36 \\
\text { tahun } 2008 \\
(\mathrm{Rp})\end{array}$ \\
\hline 1 & 810332692722000 & D & Adm. Acc \& Pay & TK & $4,548,000$ & $4,320,600$ & $51,847,200$ & $54,000,000$ & $(2,152,800)$ & $(107,640)$ & $(8,970)$ & $(107,640)$ & $(8,970)$ \\
\hline 2 & 833960883722000 & RA & Adm. Acc \& Pay & TK & $5,052,727$ & $4,697,551$ & $56,370,612$ & $54,000,000$ & $2,370,612$ & 118,531 & 9,878 & 118,531 & 9,878 \\
\hline 3 & 814288478722000 & $\mathrm{RR}$ & Adm. Acc \& Pay & TK & $4,991,400$ & $4,636,830$ & $55,641,960$ & $54,000,000$ & $1,641,960$ & 82,098 & 6,842 & 82,098 & 6,842 \\
\hline 4 & 667908131728000 & DDR & Adm. Fnc \& Tax & TK & $4,712,000$ & $4,476,400$ & $53,716,800$ & $54,000,000$ & $(283,200)$ & $(14,160)$ & $(1,180)$ & $(14,160)$ & $(1,180)$ \\
\hline 5 & 152259701722000 & HAD & Koord. Fnc \& Tax & $\mathrm{K} / 1$ & $6,602,200$ & $6,107,090$ & $73,285,080$ & $63,000,000$ & $10,285,080$ & 514,254 & 42,855 & 514,254 & 42,855 \\
\hline 6 & 819368812722000 & MY & Koord. Fnc \& Tax & $\mathrm{K} / 1$ & $6,637,200$ & $6,140,340$ & $73,684,080$ & $63,000,000$ & $10,684,080$ & 534,204 & 44,517 & 534,204 & 44,517 \\
\hline 7 & 544472517722000 & MNN & Spt. Fnc \& Tax & $\mathrm{K} / 2$ & $12,349,400$ & $11,572,365$ & $138,868,380$ & $67,500,000$ & $71,368,380$ & $5,705,257$ & 475,438 & $5,705,257$ & 475,438 \\
\hline 8 & 876436783722000 & RHM & Spv. Acc \& Pay & TK & $9,129,140$ & $8,438,648$ & $101,263,776$ & $54,000,000$ & $47,263,776$ & $2,363,189$ & 196,932 & $2,363,189$ & 196,932 \\
\hline 9 & 808911465722000 & SHS & Spv. Fnc \& Tax & TK & $9,129,140$ & $8,438,648$ & $101,263,776$ & $54,000,000$ & $47,263,776$ & $2,363,189$ & 196,932 & $2,363,189$ & 196,932 \\
\hline 10 & 827005505722000 & $\mathrm{RW}$ & Adm. GA & TK & $4,904,447$ & $4,556,685$ & $54,680,220$ & $54,000,000$ & 680,220 & 34,011 & 2,834 & 34,011 & 2,834 \\
\hline 11 & 814288346722000 & IS & Adm. HRD & TK & $4,904,447$ & $4,556,685$ & $54,680,220$ & $54,000,000$ & 680,220 & 34,011 & 2,834 & 34,011 & 2,834 \\
\hline 12 & 824995237722000 & $\mathrm{R}$ & Cleaning Service & $\mathrm{K} / 1$ & $5,831,500$ & $5,427,425$ & $65,129,100$ & $63,000,000$ & $2,129,100$ & 106,455 & 8,871 & 106,455 & 8,871 \\
\hline 13 & 824022222722000 & $\mathrm{~S}$ & Cleaning Service & $\mathrm{K} / 1$ & $4,640,387$ & $4,310,328$ & $51,723,936$ & $63,000,000$ & $(11,276,064)$ & $(563,803)$ & $(46,984)$ & $(563,803)$ & $(46,984)$ \\
\hline 14 & 168427797722000 & $\mathrm{~A}$ & HRD Officer & $\mathrm{K} / 1$ & $6,602,200$ & $6,107,090$ & $73,285,080$ & $63,000,000$ & $10,285,080$ & 514,254 & 42,855 & 514,254 & 42,855 \\
\hline 15 & 692097801726000 & $\mathrm{AY}$ & Spt. HRD \& GA & $\mathrm{K} / 2$ & $12,719,600$ & $11,942,565$ & $143,310,780$ & $67,500,000$ & $75,810,780$ & $6,371,617$ & 530,968 & $6,371,617$ & 530,968 \\
\hline 16 & $\begin{array}{l}560017766728000 \\
\end{array}$ & EA & Adm. Logistik & TK & $4,509,667$ & $4,186,144$ & $50,233,728$ & $54,000,000$ & $(3,766,272)$ & $(188,314)$ & $(15,693)$ & $(188,314)$ & $(15,693)$ \\
\hline 17 & & $\mathrm{AR}$ & Driver LV & TK & $4,580,000$ & $4,351,000$ & $52,212,000$ & $54,000,000$ & $(1,788,000)$ & $(89,400)$ & $(8,940)$ & $(89,400)$ & $(8,940)$ \\
\hline 18 & 839152782722000 & A & Driver LV & $\mathrm{K} / 1$ & $5,329,447$ & $4,960,435$ & $59,525,220$ & $63,000,000$ & $(3,474,780)$ & $(173,739)$ & $(14,478)$ & $(173,739)$ & $(14,478)$ \\
\hline 19 & 159291103722000 & ESP & Driver LV & $\mathrm{K} / 2$ & $4,779,320$ & $4,441,354$ & $53,296,248$ & $67,500,000$ & $(14,203,752)$ & $(710,188)$ & $(59,182)$ & $(710,188)$ & $(59,182)$ \\
\hline 20 & 974266686722000 & $\mathrm{JM}$ & Driver LV & TK & $4,904,447$ & $4,556,685$ & $54,680,220$ & $54,000,000$ & 680,220 & 34,011 & 2,834 & 34,011 & 2,834 \\
\hline 21 & 143170363722000 & ES & Koord. Logistik & $\mathrm{K} / 3$ & $6,637,200$ & $6,140,340$ & $73,684,080$ & $72,000,000$ & $1,684,080$ & 84,204 & 7,017 & 84,204 & 7,017 \\
\hline 22 & 841450539722000 & DN & Purchasing & TK & $5,414,447$ & $5,041,185$ & $60,494,220$ & $54,000,000$ & $6,494,220$ & 324,711 & 27,059 & 324,711 & 27,059 \\
\hline 23 & 820610897722000 & YSN & Purchasing & $\mathrm{K} / 0$ & $4,869,447$ & $4,523,435$ & $54,281,220$ & $58,500,000$ & $(4,218,780)$ & $(210,939)$ & $(17,578)$ & $(210,939)$ & $(17,578)$ \\
\hline 24 & 811274711722000 & $\mathrm{MZ}$ & Spt. Logistik & $\mathrm{K} / 2$ & $12,314,400$ & $11,537,365$ & $138,448,380$ & $67,500,000$ & $70,948,380$ & $5,642,257$ & 470,188 & $5,642,257$ & 470,188 \\
\hline 25 & 836801142066000 & $\mathrm{CDj}$ & Spt. Marketing & TK & $15,770,000$ & $15,270,000$ & $183,240,000$ & $54,000,000$ & $129,240,000$ & $14,386,000$ & $1,198,833$ & $14,386,000$ & $1,198,833$ \\
\hline 26 & & AWSRI & Adm. KTT & TK & $4,580,000$ & $4,351,000$ & $52,212,000$ & $54,000,000$ & $(1,788,000)$ & $(89,400)$ & $(8,940)$ & $(89,400)$ & $(8,940)$ \\
\hline 27. & 673831400423000 & TMH & KTT & $\mathrm{K} / 2$ & $17,196,300$ & $16,419,265$ & $197,031,180$ & $67,500,000$ & $129,531,180$ & $14,429,677$ & $1,202,473$ & $14,429,677$ & $1,202,473$ \\
\hline 28 & 486082381722000 & SW & Senior Geologist & $\mathrm{K} / 3$ & $8,033,740$ & $7,426,553$ & $89,118,636$ & $72,000,000$ & $17,118,636$ & 855,932 & 71,328 & 855,932 & 71,328 \\
\hline 29 & 706378783728000 & EPA & Adm. Dcm \& Expor1 & $1 \mathrm{~K} / 3$ & $4,904,447$ & $4,556,685$ & $54,680,220$ & $72,000,000$ & $(17,319,780)$ & $(865,989)$ & $(72,166)$ & $(865,989)$ & $(72,166)$ \\
\hline 30 & 830068797722000 & & Adm. Shipping & TK & $4,677,000$ & $4,443,150$ & $53,317,800$ & $54,000,000$ & $(682,200)$ & $(34,110)$ & $(2,843)$ & $(34,110)$ & $(2,843)$ \\
\hline 31 & 578629099721000 & & Spt. Port \& Quality & $K / 3$ & $12,859,600$ & $12,082,565$ & $144,990,780$ & $72,000,000$ & $72,990,780$ & $5,948,617$ & 495,718 & $5,948,617$ & 495,718 \\
\hline 32 & 553413535721000 & DR & Spv. Shipping & TK & $8,890,550$ & $8,217,273$ & $98,607,276$ & $54,000,000$ & $44,607,276$ & $2,230,364$ & 185,864 & $2,230,364$ & 185,864 \\
\hline
\end{tabular}

Sumber : PT. KDC, 2018

\section{PEMBAHASAN}

Berdasarkan latar belakang dan tujuan penelitian ini yaitu mengetahui perhitungan pajak penghasilan karyawan dengan status pegawai tetap pada PT. KDC Samarinda sudah sesuai atau belum dengan Undang-Undang Nomor 36 Tahun 2008 dan Peraturan Menteri Keuangan Nomor 101/PMK.010/2016.

Karyawan Head Office PT. KDC Samarinda yang terdiri dari 32 karyawan ternyata hanya 21 karyawan yang dikenakan pemotongan pajak sesuai dengan Undang-Undang Nomor 36 tahun 2008 dan Peraturan Menteri Keuangan Nomor 101/PMK.010/2016. Perhitungan Pajak Penghasilan Pasal 21 atas gaji karyawan tetap PT. KDC telah sesuai dengan peraturan Pajak Undang Undang No. 36 Tahun 2008, karena tidak didapati adanya selisih. 
22 Research Journal of Accounting and Business Management (RJABM); P-ISSN: 2580-3115; E-ISSN: 2580-3131

\begin{tabular}{|c|c|c|c|c|c|c|c|c|}
\hline No & NPWP & Nama & Jabatan & Status & $\begin{array}{c}\text { pph pasal } \\
21 \text { sebulan } \\
\text { KDC ( Rp) }\end{array}$ & $\begin{array}{c}\text { pph pasal } \\
21 \text { sebulan } \\
\text { nomor } 36 \\
\text { tahun } 2008 \\
(\mathrm{Rp})\end{array}$ & selisih ( Rp) & $\begin{array}{c}\text { keterang } \\
\text { an }\end{array}$ \\
\hline 1 & 833960883722000 & RA & Adm. Acc \& Pay & TK & 9,878 & 9,878 & - & sesuai \\
\hline 2 & 814288478722000 & RR & Adm. Acc \& Pay & TK & 6,842 & 6,842 & - & sesuai \\
\hline 3 & 152259701722000 & HAD & Koord. Fnc \& Tax & $\mathrm{K} / 1$ & 42,855 & 42,855 & - & sesuai \\
\hline 4 & 819368812722000 & MY & Koord. Fnc \& Tax & $\mathrm{K} / 1$ & 44,517 & 44,517 & - & sesuai \\
\hline 5 & 544472517722000 & MNN & Spt. Fnc \& Tax & $\mathrm{K} / 2$ & 475,438 & 475,438 & - & sesuai \\
\hline 6 & 876436783722000 & RHM & Spv. Acc \& Pay & TK & 196,932 & 196,932 & - & sesuai \\
\hline 7 & 808911465722000 & SHS & Spv. Fnc \& Tax & TK & 196,932 & 196,932 & - & sesuai \\
\hline 8 & 827005505722000 & RW & Adm. GA & TK & 2,834 & 2,834 & - & sesuai \\
\hline 9 & 814288346722000 & IS & Adm. HRD & TK & 2,834 & 2,834 & - & sesuai \\
\hline 10 & 824995237722000 & $\mathrm{R}$ & Cleaning Service & $\mathrm{K} / 1$ & 8,871 & 8,871 & - & sesuai \\
\hline 11 & 168427797722000 & $\mathrm{~A}$ & HRD Officer & $\mathrm{K} / 1$ & 42,855 & 42,855 & - & sesuai \\
\hline 12 & 692097801726000 & AY & Spt. HRD \& GA & $\mathrm{K} / 2$ & 530,968 & 530,968 & - & sesuai \\
\hline 13 & 974266686722000 & $\mathrm{JM}$ & Driver LV & TK & 2,834 & 2,834 & - & sesuai \\
\hline 14 & 143170363722000 & $\mathrm{ES}$ & Koord. Logistik & $\mathrm{K} / 3$ & 7,017 & 7,017 & - & sesuai \\
\hline 15 & 841450539722000 & $\mathrm{DN}$ & Purchasing & TK & 27,059 & 27,059 & - & sesuai \\
\hline 16 & 811274711722000 & $\mathrm{MZ}$ & Spt. Logistik & $\mathrm{K} / 2$ & 470,188 & 470,188 & - & sesuai \\
\hline 17 & 836801142066000 & $\mathrm{CDj}$ & Spt. Marketing & TK & $1,198,833$ & $1,198,833$ & - & sesuai \\
\hline 18 & 673831400423000 & $\mathrm{TMH}$ & KTT & $\mathrm{K} / 2$ & $1,202,473$ & $1,202,473$ & - & sesuai \\
\hline 19 & 486082381722000 & SW & Senior Geologist & $\mathrm{K} / 3$ & 71,328 & 71,328 & - & sesuai \\
\hline 20 & 578629099721000 & $\mathrm{M}$ & Spt. Port \& Quality & $\mathrm{K} / 3$ & 495,718 & 495,718 & - & sesuai \\
\hline 21 & 553413535721000 & $\mathrm{DR}$ & Spv. Shipping & TK & 185,864 & 185,864 & - & sesuai \\
\hline \multicolumn{5}{|c|}{ Total } & $5,223,070$ & $5,223,070$ & - & \\
\hline
\end{tabular}

Sumber : PT. KDC dan Hasil Analisis Penelitian, 2018

Menurut analisa data yang diperoleh terkait dengan pelaksanaan pemotongan pajak penghasilan yang dilakukan PT. KDC Samarinda kepada karyawan dengan status pegawai tetap sudah sesuai dengan $\mathrm{PPh}$ pasal 21 ayat (3) Undang-Undang Nomor 36 tahun 2008 yaitu "penghasilan pegawai tetap atau pensiunan yang dipotong pajak setiap bulan adalah jumlah penghasilan bruto setelah dikurangi dengan biaya jabatan atau biaya pensiun yang besarnya ditetapkan dengan Peraturan Menteri Keuangan, iuran pensiun, dan Penghasilan Tidak Kena Pajak dan Peraturan Menteri Keuangan tentang penyesuaian besarnya penghasilan tidak kena pajak dan Perhitungan pajak penghasilan karyawan dengan status pegawai tetap yang tidak memiliki Nomor Pokok Wajib Pajak ( NPWP ) sudah sesuai dengan ketentun PPh pasal 21 ayat (5a) Undang - Undang Nomor 36 Tahun 2008 yaitu besarnya tarif sebagaimana dimaksud pada aayat (5) yang diterapkan terhadap wajib pajak yang tidak memilik NPWP lebih tinggi 20\% (dua puluh persen ) dari tarif yang diterapkan terhadap Wajib Pajak yang memiliki Nomor Pokok Wajib Pajak (NPWP).

Secara keseluruhan terdapat persamaan dalam perhitungan pajak penghasilan karyawan pada PT. KDC Samarinda dengan Undang-Undang Nomor 36 tahun 2008 tentang pajak penghasilan dan 
101/PMK.010/2016.

\section{KESIMPULAN DAN SARAN}

\section{Kesimpulan}

Berdasarkan hasil penelitian dan pembahasan yang dilakukan atas perhitungan pajak penghasilan (PPh) karyawan dengan status karyawan tetap pada PT. KDC, penulis menyimpulkan bahwa:

1. Pelaksanaan Perhitungan Pajak

Penghasilan Karyawan dengan Status Pegawai Tetap Di PT. KDC Samarinda sudah sesuai dengan Undang-Undang Nomor 36 tahun 2008 Dan Peraturan Menteri Keuangan Nomor 101/PMK.010/2016 dengan demikian hipotesis ditolak.

2. Hasil pembahasan dapat diketahui perhitungan pajak penghasilan $(\mathrm{PPh})$ Pasal 21 yang di analisis dari jumlah karyawan Head Office 32 Orang yang

\section{Saran}

Berdasarkan kesimpulan yang telah penulis jabarkan diatas maka penulis memberikan sedikit saran-saran yang diharapkan bermanfaat bagi pembaca dan pihak-pihak yang berkepentingan. Beberapa terkena Pajak Penghasilan (PPh) pasal 21 hanya 21 orang. PT. KDC di Samarinda untuk bulan Februari 2018 harus menyetor ke kas Negara sebesar Rp. 5.223.070,- sedangkan perhitungan pajak penghasilan yang dipotong/dipungut berdasarkan analisis pada bulan Februari tahun 2018 sebesar Rp. 5.223.070,-. dapat disimpulkan bahwa hasil dari penelitian sudah sesuai dengan UndangUndang Nomor 36 tahun 2008 dan Peraturan Menteri Keuangan Nomor 101/PMK.010.2016. yang ingin penulis sampaikan adalah sebagai berikut:

1. Sebaiknya perhitungan pajak penghasilan $(\mathrm{PPh})$ pasal 21 yang sudah sesuai dengan Undang-Undang Nomor 36 tahun 2008 
dan Peraturan Menteri Keuangan Nomor 101/PMK.010/2016 harus tetap di pertahankan.

2. Kiranya Perusahaan mengupdate data mengenai perkembangan ketentuan

\section{DAFTAR PUSTAKA}

Anonim, 2008, Undang-Undang Nomor 36 Tahun 2008 Tentang Pajak Penghasilan

,2016, Peraturan Menteri Keuangan Nomor 101/PMK.010/2016

2016, Peraturan Direktur Jendral Pajak Nomor PER-16/PJ/2016

Agoes, Sukrisno Dan Estralita Trisnawati, 2013, Akuntansi Perpajakan Edisi 3, Jakarta, Salemba Empat

Dalushu, Meyliza, 2015, Analisis Perhitungan Dan Pemotongan PPh Pasal 21 Pada karyawan PT.BPR Primaesa Sejahtera Manado, Universitas Sam Ratulangi Manado.

Diana, Anastasia dan Lilis Setiawati, 2009, Perpajakan Indonesia Konsep, Aplikasi dan Penuntun Praktis, CV.Andi Offset, Yogyakarta

Mardiasmo, 2016, Perpajakan Edisi Terbaru 2016, CV.Andi Offset, Yogyakarta

Muljono, Djoko, 2009,Akuntansi Pajak, CV.Andi Offset, Yogyakarta perpajakan yang disesuaikan oleh pemerintah, mengingat peraturan perundang-undangan perpajakan yang berlaku di Indonesia sering mengalami perubahan.

Pangandaheng, Vinry Y, Inggriani Elim, Heince R.N Wokas, 2017, Analisis Perhitungan PPh Pasal 21 Terhadap Pegawai Tetap Atas Berlakunya PMK RI No 101/PMK.010/2016 Tentang PTKP Studi Kasus Pada PT. Bank Sulutgo Cabang Tahuna.

Riyono, 2014, Akuntansi Pengantar 1, edisi kesembilan, Sekolah Tinggi Ilmu Manajemen YKPN, Yogyakarta.

Supramono \& Theresia Woro Damayanti, 2010, Perpajakan Indonesia Mekanisme dan Perhitungan, CV.Andi Offset, Yogyakarta

Susan,Jeane, 2013, Analisis Perhitungan Pajak Penghasilan Pasal 21 Pada PT. Megasurya Nusalestari Manado,Universitas Sam Ratulangi Manado.

James M,Reeve. Et Al, 2013, Pengantar Akuntansi Adaptasi Indonesia Buku 2, Salemba Empat, Jakarta 